\title{
HUBUNGAN ANTARA KOMUNIKASI DAN PENGAMBILAN KEPUTUSAN DENGAN KINERJA KEPALA SEKOLAH DASAR NEGERI DI WILAYAH JAKARTA TIMUR
}

\author{
Oleh: Resmin Sihotang1
}

Abstract. The objective of the research is to obtain the relationship between communication with the headmasters' performance, decision making with the headmasters' performance, communication and decision making with the headmasters' performance in subdistrict Kramat Jati East Jakarta. The research method used is survey method with correlation and regression approach. The respondents were elementary headmasters' who are at subdistrict Kramat Jati East Jakarta as many as 75 samples selected by simple random sampling technique. The finding of the research are: (1) there is a positive relationship between communication with performance; (2) there is a positive relationship between decision making with performance; and (3) there is a positive relationship between communication and decision making with performance.Based on these findings, it could be concluded that any changing or variation occured at headmasters' performance might have been associate with communication and decision making. To minimaze the variation which occurred in headmasters' performance, these factors such as communication and decision making are necessary to be taken into account.

Keyword: communication, decision making, performance.

\section{PENDAHULUAN}

Manajemen berbasis sekolah sejak diberlakukannya pada tahun 1999/2000 hingga saat ini masih terus-menerus mencari bentuk ideal penerapannya di lapangan. Idealnya penataan sekolah melalui konsep MBS yang diartikan sebagai wujud dari reformasi pendidikan, diarahkan untuk meredesain dan memodifikasi struktur pemerintah menjadi sekolah yang berkonsep pemberdayaan sekolah. Fokus pemberdayaan tersebut dimaksudkan untuk meningkatkan otonomi dan profesionalisme sekolah yang pada gilirannya meningkatkan kualitas pendidikan. Implementasi MBS ini tidak sekedar membawa perubahan kewenangan dalam akademik di sekolah, tetapi juga membawa perubahan mendasar dalam hal kebijakan dan orientasi partisipasi orang tua dan masyarakat.

Maka manajemen berbasis sekolah sebagai sebuah pendekatan baru dalam manajemen pendidikan dirasakan mampu menjadi solusi untuk menghasilkan para lulusan yang kompeten karena lebih menekankan pemberian otonomi pada sekolah untuk menentukan kebijakan sekolah dalam rangka meningkatkan mutu, efisiensi dan pemerataan pendidikan agar dapat mengakomodasi keinginan masyarakat setempat serta menjalin kerjasama yang erat antara sekolah, masyarakat dan pemerintah.

Diharapkan dengan adanya semangat Manajemen Berbasis Sekolah dapat menyediakan pendidikan yang lebih baik dan lebih memadai bagi peserta didik karena MBS memberi peluang bagi kepala sekolah, guru, dan peserta didik untuk melakukan inovasi di sekolah, baik yang terkait dengan masalah kurikulum, pembelajaran, pembiayaan dan lain sebagainya yang tumbuh dari aktivitas, kreativitas, dan profesionalitas yang dimiliki dalam rangka meningkatkan mutu pendidikan. Kepala sekolah dalam hal ini memiliki kewenangan penuh untuk mengelola sekolah agar lebih

\footnotetext{
${ }^{1}$ Kepala Sekolah Dasar Negeri Dukuh 03 Kramat Jati, Jakarta Timur
} 
baik, semua aspek difikirkan pengelolaannya, baik pengelolaan pendidik dan tenaga kependidikan, keuangan, kurikulum, sarana prasarana, dan lain-lain.

Maka dari itu kepala sekolah sebagai pimpinan sekolah harus menunjukkan kinerja yang tinggi agar visi dan misi yang telah disepakati bersama warga sekolah dapat tercapai dan dijadikan alat ukur keberhasilan melaksanakan pekerjaan. Kinerja menurut George and Jones (2005:176) diartikan sebagai,"performance is an evaluation of the results of a person's behavior : it involves determining how well or poorly a person has accomplished a task or done a job". Kinerja merupakan hasil penilaian dari perilaku seseorang, yang berkaitan dengan penentuan dari seberapa baik atau buruknya seseorang setelah menyelesaikan tugasnya atau melakukan pekerjaannya. Sedangkan Slocum dan Hellriegel (2009:127) mendefinisikan kinerja sebagai,"a function of a person's level of ability and motivation". Fungsi dari tingkat kemampuan dan motivasi seseorang. Seseorang akan memiliki kinerja yang baik jika ia memiliki motivasi yang tinggi dan juga disertai dengan kemampuan yang tinggi.

Untuk mengetahui seberapa baik atau buruk seseorang dalam menyelesaikan tugasnya dapat dilihat dari karakteristik atau indikator kinerja. Menurut Gary Dessler (1997:6), indikator kinerja secara umum dapat dilihat dari: (1) mutu (kecermatan, ketuntasan dan dapat diterimanya kerja yang dilaksanakan; (2) produktivitas (jumlah dan efisiensi dari kerja yang dihasilkan dalam periode waktu tertentu); (3) pengetahuan jabatan (keterampilan dan informasi praktis/ teknis yang digunakan pada jabatan; (4) kehandalan (sejauh mana seseorang dapat diandalkan menyangkut penyelesaian tugas dan tindak lanjut; (5) ketersediaan (sejauh mana seseorang tepat pada waktunya, meninjau periode yang ditetapkan dan catatan kehadiran keseluruhan.

Berdasarkan pengamatan yang dilakukan, peneliti masih menemukan rendahnya kinerja kepala sekolah terutama Kepala Sekolah Dasar. Hal ini dapat dilihat dari beberapa hal, diantaranya : Kepala sekolah tidak menjalankan tugasnya sebagai guru yang wajib mengajar $6 \mathrm{JPL} /$ minggu, kepala sekolah tidak memberikan supervisi secara rutin, yang seharusnya dilaksanakan minimal $3 \times$ dalam 1 semester, jadwal kehadiran dan kepulangan kepala sekolah pun tidak sesuai jadwal yang ditetapkan, terkadang datang terlambat tetapi pulang lebih awal, dan terakhir kurangnya transparansi kepala sekolah dalam penggunaan dana BOP dan BOS, kurangnya perawatan sekolah, serta sarana dan prasarana yang kurang memadai. Hal-hal tersebut dapat dijadikan sebagai salah satu indikator rendahnya kinerja kepala sekolah, Maka dari itu, perlu dilakukan beberapa upaya dalam rangka meningkatkan kinerja kepala sekolah.

Terdapat banyak faktor yang berhubungan dengan kinerja kepala sekolah, diantaranya adalah komunikasi dan pengambilan keputusan. Komunikasi sangat berperan penting bagi kelancaran kegiatan. Jennifer M. George and Gareth R. Jones (2005:437) mendefinisikan komunikasi sebagai, "communication the sharing of information between two or more individuals or groups to reach a common understanding." Hal ini berarti komunikasi sebagai pembagian informasi diantara dua atau lebih orang-orang atau kelompok untuk mencapai pemahaman yang sama.

Informasi/pesan yang diterima dan dipahami dengan baik, menjadikan komunikasi berjalan efektif.

Selain komunikasi, pengambilan keputusan juga memiliki peran yang cukup penting dalam meningkatkan kinerja kepala sekolah. Colquitt, LePine, Wesson (2008:256) menyatakan pengambilan keputusan merupakan proses menghasilkan dan memilih lebih dari satu alternatif dalam memecahkan masalah (decision making, the process of generating and choosing from a set of alternatives to solve a problem). Dalam 
mengambil keputusan, kepala sekolah dihadapkan pada pemilihan alternatif terbaik dari beberapa alternatif yang ada. Sehingga dalam memilih alternatif terbaik kepala sekolah diupayakan agar dapat bersikap tegas, mengumpulkan informasi secara maksimal, bersikap hati-hati, melibatkan seluruhwarga sekolah, berani mengambil resiko, kreatif, dan suportif. Dengan komukasi yang efektif serta pengambilan keputusan yang tepat diharapkan dapat meningkatkan kinerja kepala sekolah.

Berdasarkan uraian di atas, peneliti memandang perlu melakukan kajian tentang komunikasi dan pengambilan keputusan hubungannya dengan kinerja yang dimiliki para kepala Sekolah Dasar Negeri di Kecamatan Kramat Jati Jakarta Timur.

\section{Kinerja}

Setiap organisasi menginginkan agar para anggota yang berada didalamnya dapat menunjukkan kinerja mereka secara optimal. Karena keberhasilan dalam melakukan suatu pekerjaan sangat ditentukan oleh kinerja.seseorang yang berkinerja tinggi, secara langsung maupun tidak langsung akan membawa dampak positif bagi organisasi tersebut. Mengingat betapa pentingnya kinerja di dalam suatu organisasi, banyak para ahli manajemen melakukan penelitian terkait kinerja.

Menurut Colquitt (2009:36), "job performance is formally defined as the value of the set of employee behaviors that contribute, either positively or negatively, to organizational goal accomplishment." Kinerja merupakan nilai dari himpunan perilaku karyawan yang memberikan kontribusi, baik positif maupun negatif, untuk pencapaian tujuan organisasi. Dari definisi tersebut diketahui bahwa kontribusi seseorang tidak selalu positif, dapat juga berupa kontribusi negatif, akan tetapi semuanya diarahkan untuk pencapaian tujuan organisasi.

Definisi selanjutnya dikemukakan oleh Nelson dan Quick (2006:191) yang mengartikan kinerja sebagai, "ketuntasan kerja (task accomplishment) yang terlihat dari hasil-hasil yang ada (outcomes) dan usaha (effort) sebagai kinerja yang baik (good performance)". Kerja yang tuntas mengindikasikan bahwa kinerja berkaitan dengan perilaku seseorang dalam mengemban tugas dengan tanggung jawab dan keahlian yang dimilikinya. Ketuntasan juga menggambarkan hasil yang berkualitas sebagai bagian dari ketelitian, kecermatan dan kemampuan dalam melakukan pekerjaan, serta berhubungan erat dengan usaha-usaha dalam melaksanakan tanggung jawab tersebut dalam rangka memberikan kinerja yang baik (good performance).

Berbeda dari definisi-definisi sebelumnya, Robbins and Coulter (2007:564) mendefinisikan,"performance as the end result of an activity". Kinerja sebagai hasil akhir dari kegiatan. Dari definisi tersebut tersirat bahwa untuk mengetahui kinerja seseorang maka harus dilihat di akhir kegiatan, kinerja seseorang dikatakan bagus jika kegiatan yang dilakukannya sesuai dengan tanggung jawab yang dibebankan kepadanya, dengan kata lain pekerjaan yang diselesaikannya sesuai dengan target yang harus dicapai.

Diperkuat oleh Rivai dan Basri (2005:14) yang mengatakan bahwa kinerja adalah hasil atau tingkat keberhasilan seseorang secara keseluruhan selama periode tertentu dalam melaksanakan tugas dibandingkan dengan berbagai kemungkinan, seperti standar hasil kerja, target atau sasaran, serta kriteria yang telah ditentukan terlebih dahulu dan disepakati bersama-sama. Dari beberapa definisi yang telah dikemukakan di atas maka dapat disintesiskan bahwa kinerja merupakan hasil perolehan kerja individu dalam menyelesaikan tugasnya. 
Hasil perolehan kerja individu dalam menyelesaikan tugasnya dapat dilihat dari karakteristik atau indikator kinerja. Menurut Gary Dessler (2001:275), indikator kinerja secara umum dapat dilihat dari: (1) mutu (kecermatan, ketuntasan dan dapat diterimanya kerja yang dilaksanakan; (2) produktivitas (jumlah dan efisiensi dari kerja yang dihasilkan dalam periode waktu tertentu); (3) kehandalan (sejauh mana seseorang dapat diandalkan menyangkut penyelesaian tugas dan tindak lanjut; (4) ketersediaan (sejauh mana seseorang tepat pada waktunya, meninjau periode yang ditetapkan dan catatan kehadiran keseluruhan.

George and Jones (2005:179) meringkasnya menjadi tiga indikator, yaitu: quality of work, quantity of work, and level of customer service. Hal ini di jabarkan lebih lanjut oleh Gibson et al (2006:372-373) bahwa hasil akhir dari kinerja yaitu dapat berupa:

a. Objective outcomes: quantity and quality of output, absenteeism, tardiness, and turnover are objective outcomes that can measured in quantitative terms.

b. Personal behavior outcomes: the jobholder reacts to the work itself. She react by either attending regularly or being absent, by staying with the job or by quitting.

c. Intrinsic and extrinsic outcomes. An intrinsic outcomes is an object or event that follows from the worker's own efforts and doesn't require the involvement of any other person. Extrinsic outcomes are objects or evants that follow from the worker's own effort in conjunction with other factors or persons not directly involved in the job itself.

Hasil akhir dari kinerja menurut Gibson et al antara lain berupa:

a. Hasil Tujuan: kuantitas dan kualitas output, absensi, keterlambatan, dan pergantian merupakan hasil objektif yang dapat diukur secara kuantitatif.

b. Hasil Perilaku pribadi: pegawai memberikan reaksi terhadap pekerjaannya. Dia bereaksi dengan datang secara teratur atau tidak datang, dengan tetap bekerja atau dengan berhenti.

c. Hasil Intrinsik dan ekstrinsik. Sebuah hasil intrinsik adalah obyek atau kegiatan berdasarkan usaha sendiri dan tidak memerlukan keterlibatan orang lain. hasil ekstrinsik adalah obyek atau kegiatan berdasarkan usaha sendiri dalam hubungannya dengan faktor-faktor lain atau orang lain yang secara tidak langsung terlibat dalam pekerjaan itu sendiri.

Dari beberapa pendapat yang telah dikemukakan di atas maka dapat disintesiskan bahwa kinerja merupakan hasil perolehan kerja individu dalam menyelesaikan tugasnya yang meliputi : kualitas kerja, kuantitas kerja, dapat diandalkan, dan memiliki inisiatif.

\section{Komunikasi}

Banyak definisi dari komunikasi yang dikemukakan oleh para ahli, mereka mendefinisikan menurut sudut pandang yang berbeda. Untuk mendapatkan gambaran yang lebih jelas mengenai pengertian komunikasi, berikut dikemukakan pendapat dari beberapa ahli. Robbins and Judge (2011:376)n berpendapat bahwa, "communication is the transfer and the understanding of meaning". Komunikasi merupakan pemindahan dan pemahaman arti/makna. Menurut Debra L. Nelson (2006:250), "communication is the evoking of a shared or common meaning in another person". Komunikasi merupakan sebuah usaha membangkitkan sebuah makna umum dengan orang lain.

Sedangkan menurut kreitner and Kinicki (2007:439) komunikasi diartikan sebagai, "the exchange of information between a sender and a receiver, and the inference (perception) of meaning between the individuals involved". Komunikasi merupakan pertukaran informasi 
antara pengirim dan penerima, dan mempersepsikan makna antara individu yang terlibat. Komunikasi diartikan pula sebagai, "the sharing of information between two or more individuals or groups to reach a common understanding". Komunikasi merupakan pertukaran informasi antara dua atau lebih individu atau kelompok untuk mendapatkan pemahaman bersama. Definisi serupa dikemukakan oleh McShane and Von Glinow (2008:314) yang menyatakan, "communication refers to the process by which information is transmitted and understood between two or more people". Komunikasi mengacu pada proses dimana informasi ditransmisikan dan di pahami oleh dua atau lebih individu.

Dari beberapa definisi di atas dapat diketahui bahwa dalam komunikasi harus melibatkan sedikitnya dua orang individu, selain itu ada pertukaran informasi sehingga diperoleh pemahaman bersama. Dengan kata lain komunikasi baru dapat berjalan dengan baik jika pesan yang ingin disampaikan oleh pengirim dapat dipahami oleh penerima.

Lebih lanjut Gary Dessler (2001:362) mendefinisikan komunikasi sebagai, "the exchange of information and the transmission of meaning". Komunikasi diartikan sebagai pertukaran informasi dan pengiriman makna. Komunikasi tidak cukup dengan saling bertukar informasi akan tetapi lebih dari itu, komunikasi baru dapat berjalan efektif jika pesan yang ingin disampaikan dipahami oleh kedua belah pihak. Sedangkan Ivancevich, et al (2008:351) mendefinisikan komunikasi sebagai, "communication as the transmission of information and understanding though the use of common symbols from one person or group to another. The common symbols maybe verbal or non verbal". Komunikasi sebagai penyampaian informasi dan pemahaman dengan menggunakan simbol-simbol umum dari satu orang atau kelompok kepada yang lainnya, baik simbol verbal maupun non verbal.

Robert P. Vecchio (2006:294), mengatakan bahwa: Comumunication the exchange of messages between persons for the purpose of constructing common meanings. Communication is the creation of a mental image in the mind of a receiver in exactly the same detail as intended by the sender. Komunikasi merupakan pertukaran pesan diantara orang-orang dengan tujuan menyamakan arti pesan. Komunikasi adalah penciptaan gambaran mental dalam pikiran penerima persis sama sebagaimana yang dimaksud oleh pengirim.

Dari berbagai definisi di atas maka dapat disintesiskan bahwa komunikasi merupakan pertukaran informasi antara dua atau lebih individu atau kelompok dengan menggunakan simbol-simbol, baik simbol verbal maupun non verbal untuk mendapatkan pemahaman bersama.

Dalam berkomunikasi, di dalamnya terjadi sebuah proses mulai dari pengiriman pesan sampai pada penerimaan pesan. Secara lebih jelas proses komunikasi dapat dilihat pada gambar berikut: 


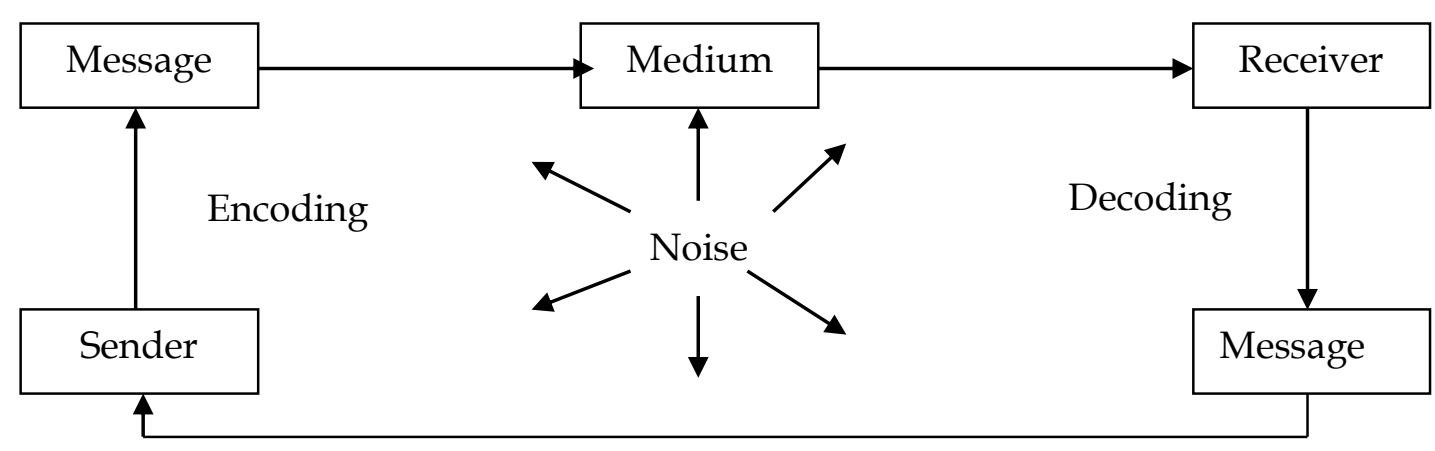

Feedback

Gambar 1

Communication Process

a. A Sender adalah seseorang yang memiliki ide-ide, intensitas, informasi, dan tujuan dari komunikasi.

b. Encoding adalah proses penciptaan ide-ide atau pesan yang akan dikirimkan oleh komunikator.

c. Message adalah suatu gagasan dan ide berupa,pesan atau informasi, pengetahuan, ajakan, bujukan atau ungkapan yang akan disampaikan komunikator pada seseorang atau kelompok tertentu.

d. Medium adalah sarana atau saluran yang dipergunakan oleh komunikator dalam mekanisme penyampaian pesan. Media komunikasi sangat banyak jenisnya, seperti: Email, telpon, surat, rapat-rapat, pesan singkat (SMS), faximile, koran, majalah, seminar dan lain-lain.

e. Receiver adalah seseorang yang menerima pesan dari communicator.

f. Decoding adalah proses menterjemahkan simbol-simbol yang diterima oleh komunikan atau penerima pesan.

g. Feed back adalah respon terhadap pesan yang diterima.

Dari gambar tersebut, dalam komunikasi ternyata membutuhkan proses yang cukup panjang dan dibantu pula oleh berbagai sarana agar pesan dapat diterima dengan baik oleh penerima sehingga diperoleh pemahaman bersama.

Dalam mewujudkan komunikasi yang efektif menurut para ahli banyak hambatan-hambatan, seperti: Menurut Jennifer M. George \& Gareth R. Jones (2005:448), yaitu "Filtering and information distortion; Poor listening, Lack of or inappropriate feedback, Rumor and the grapevine, Workforce diversity, Diffences in cross-cultural linguistic style". Sedangkan menurut James L. Gibson dkk (2006:552) yaitu: “1) Semantic problems, 2) Filtering, 3) In-group language, 4) Status differences, 5) Time pressures, 6) Selective listening, 7) Value Judgment, 8) Source credibility, 9) Frame of reference 10) Proxemic behavior, 11) Communication overload".

Sedangkan Donald C. Mosley dkk (2005:169) Mengelompokkan hambatanhambatan dalam komunikasi yang efektif menjadi dua, yaitu: 1) "Organizational barriers; layers of hierarchy, authority and status, specialization and its related jargon; 2) Interpersonal and language barriers; differing perceptions, language-related factors, and linguistic styles". Adapun Ivancevich et al (2008:363-366) menyebutkan beberapa hambatan komunikasi, antara lain: "1) frame of reference, 2) selective listening, 3) value judgment, 4) source credibility, 5) 
filtering, 6) in-group language, 7) status differences, 8) time pressures, and 9) communicationa overload."

Dengan diketahuinya beberapa hambatan dalam komunikasi yang efektif selanjutnya kita harus mampu mengatasinya. Terdapat beberapa pendapat tentang bagaimana usaha mengembangkan komunikasi organisasi efektif. Menurut James L. Gibson dkk (2006:448-449) adalah: a) Following up, b) Regulating information flow, c) Utilizing feedback, d) Empathy, e) Repetition, f) Encouraging mutual trust, g) Effective timing, h) Simplifying language, i) Effective listening

Berdasarkan pemaparan di atas maka dapat disintesiskan yang dimaksud komunikasi adalah proses penyampaian informasi yang dilakukan oleh seseorangdengan menggunakan simbol-simbol, baik simbol verbal maupun non verbal untuk mendapatkan pemahaman bersama yang meliputi : pengaturan arus informasi, empati, melakukan tindak lanjut, memberikan penjelasan ulang, ketepatan waktu, penggunaan bahasa sederhana, dan pendengar efektif.

\section{Pengambilan Keputusan}

Pengambilan keputusan merupakan kegiatan inti bagi seorang pemimpin.Kegiatan ini memainkan peranan penting terutama dalam hal melaksanakan fungsi perencanaan karena perencanaan menyangkut keputusan-keputusan sangat penting dan jangka panjang yang dapat dibuat oleh pemimpin. Dalam proses perencanaan, pemimpin memutuskan tujuan-tujuan organisasi yang akan dicapai, sumber daya yang akan digunakan, dan siapa yang akan melaksanakan setiap kegiatan. Kualitas keputusan pemimpin akan menentukan efektivitas rencana yang disusun.

Pengambilan keputusan (decision making) pada umumnya diproses oleh pengambil keputusan (decision maker) yang hasilnya merupakan suatu keputusan (decision). Sebagaimana yang dikemukakan oleh Kreitner and Kinicki (2007:372) yang mengatakan, "decision making identifiying and choosing solutions that lead to a desired state of affairs. The process begins with a problem and ends when a solution has been chosen." Pengambilan keputusan sebagai proses mengidentifikasi dan memilih solusi yang mengarah kepada hasil akhir yang diinginkan. Proses ini diawali dengan masalah dan berakhir apabila penyelesaian telah dipilih. Nelson and Quick (2006:181) mengatakan, "decision making is a critical activity in the lives of managers". Pengambilan keputusan merupakan kegiatan penting dalam kehidupan manajer. Dikatakan sebagai kegiatan penting karena keputusan yang tetapkan akan berdampak panjang bagi keberlangsungan organisasi.

Selanjutnya Colquitt, LePine, and Wesson (2009:256) menyatakan, "decision making, the process of generating and choosing from a set of alternatives to solve a problem." Pengambilan keputusan sebagai proses menghasilkan dan memilih lebih dari satu alternatif dalam memecahkan masalah. Pendapat serupa dikemukakan oleh McShane and Von Glinow (2008:226) yang mengemukakan, "decision making is a conscious process of making choices among one or more alternatives with the intention of moving toward some desired state of affairs." Pengambilan keputusan sebagai proses membuat pilihan diantara satu atau lebih alternatif dengan maksud mengarah pada apa yang diharapkan.

Pendapat yang sedikit berbeda dikemukakan oleh George and Jones (2005:471) yang mendefinisikan, "decision making can be defined as the process by which members of an organization choose a specific course of action to respond to the opportunities and problems that confront them." Pengambilan keputusan sebagai proses di mana anggota organisasi memilih aksi tertentu untuk merespon peluang dan masalah yang mereka hadapi.

Sedangkan Gary Dessler (2001:98) menyatakan, "a decision is a choice from among 
the available alternatives. Decision making is the process of developing and analyzing alternatives and making a choice." Keputusan adalah pilihan di antara alternatif yang tersedia. Keputusan adalah proses mengembangkan dan menganalisis alternatif dan membuat pilihan. Pendapat yang serupa dikemukakan oleh Robbins and Judge (2011:181) yang menyatakan, "decision is choices made from among two or more alternatives." Keputusan adalah pilihan dari dua atau lebih alternatif.

Pendapat terakhir dikemukakan oleh Ivancevich et al (2008:384) yang mendefinisikan keputusan sebagai, "a means to achieve some results or to solve some problem. The outcome of a process that is influenced by many forces". Cara untuk mencapai beberapa keputusan atau menyelesaikan beberapa masalah. Hasil dari suatu proses yang dipengaruhi oleh banyak kekuatan.

Dari beberapa pendapat yang telah dikemukakan oleh para ahli maka dapat disintesiskan bahwa pengambilan keputusan merupakan proses memilih aksi tertentu untuk merespon peluang dan masalah yang dihadapi oleh seseorang.

Dalam pengambilan keputusan, terdapat beberapa model yang dapat digunakan. Secara garis besar terdapat dua model pengambilan keputusan: (1) model pengambilan keputusan klasik, dan (2) model administrasi pengambilan keputusan (Two models of decision making process: (1) the classical decision making model; and (2) the adminitrative decision making model). Menurut James March and Herbert Simons (2005:474): The classical decision making model rests on two assumptions: (1) people have access to all the information they need to make a decision, and (2) people make decisions by choosing the best possible solution to a problem or response to an opportunity. Menurutnya model pengambilan keputusan klasik didasarkan pada dua asumsi: (1) orang memiliki akses ke semua informasi yang mereka butuhkan untuk membuat keputusan, dan (2) orang membuat keputusan dengan memilih solusi terbaik terhadap masalah atau respons terhadap peluang.

Lebih lanjut dikatakan:Four steps the classical decision making model: (1) listing all alternatives from which a choice will be selected. These alternatives represent different responses to the problem or the opportunity; (2) linting the consequences of each alternative. The consequence are what would occur if a given alternative were selected; (3) considering his or her own preferences for each alternative or set of consequences and then ranking the sets from most preferred to least preferred; (4) selecting the alternative that will result in the most preferred set of consequences

Empat langkah pembuatan keputusan model klasik: (1) daftar semua alternatif dari berbagai pilihan yang akan dipilih. Alternatif-alternatif ini merupakan respons berbeda terhadap masalah atau peluang, (2) lihat konsekuensi dari setiap alternatif. Konsekuensinya adalah apa yang akan terjadi jika lternatif yang diberikan adalah yang dipilih; (3) mempertimbangkan preferensi sendiri pada setiap alternatif atau serangkaian konsekuensi dan kemudian buat peringkat yang paling disukai hingga paling tidak disukai, (4) memilih alternatif yang akan menghasilkan konsekuensi yang paling disukai.

Lebih lanjut March and Herbert Simon menyatakan: Administrative decision making model is descriptive; it explains how people actually make decisions in organizations. March and Simon stress that incomplete information and decision maker's cognitive abilities and psychological makeup affect decision making. Consequently decision makers often choose satisfactory, not optimal, solutions.

Model pengambilan keputusan administratif adalah bersifat deskriptif, tetapi menjelaskan bagaimana orang benar-benar membuat keputusan dalam organisasi. March dan Simon menekankan bahwa informasi yang tidak lengkap akan 
mempengaruhi pengambilan keputusan. Akibatnya pengambil keputusan sering memilih keputusan yang memuaskan, dan bukan solusi optimal.

Metode yang dapat digunakan dalam pengambilan keputusan terdiri atas dua metode, yaitu: keputusan terprogram dan tak terprogram. keputusan terprogram (mengidentifikasi masalah, apakah masalah dikenali, telah ditangani sebelumnya; menerapkan solusi yang tepat, apakah solusi memberikan hasil yang diharapkan), (2) keputusan tak terprogram (mengidentifikasi masalah; apakah masalah telah dikenali, telah ditangani sebelumnya; menentukan kriteria untuk pengambilan keputusan; menghasilkan daftar alternatif yang tersedia, mengevaluasi alternatif kriteria, memilih solusi yang memaksimalkan nilai, menerapkan solusi yang tepat, apakah solusi memberikan hasil sesuai yang diharapkan.

Untuk menghasilkan keputusan yang efektif, maka perlu dilakukan beberapa tahapan dalam pengambilan keputusan dengan mempertimbangkan faktor internal maupun eksternal organisasi. Ivancevich,et.al (2008:385) mengemukakan 9 tahap pengambilan keputusan yaitu:

Pertama, Menetapkan tujuan dan target spesifik dan pengukuran hasil.Organisasi perlu menetapkan tujuan dan sasaran dalam setiap bidang. Tujuan dan sasaran ini diperlukan untuk mengukur keefektifan organisasi. Jika tujuan dan sasaran ini ditetapkan dengan jelas, pimpinan dapat mengukur apakah hasil yang dicapainya sesuai dengan tujuan yang ditetapkan sebelumnya; Kedua, Identifikasi dan definisi masalah. Langkah kedua dalam pengambilan keputusan adalah mendefinisikan masalah. Mengetahui kritis tidaknya suatu persoalan ditentukan oleh besarnya perbedaan antara sasaran yang ditetapkan dan hasil yang benar-benar dicapai; Ketiga, Menetapkan prioritas. Tidak semua masalah memiliki tingkat kesulitas yang sama. Petakan masalah berdasarkan tiga isu, yaitu: urgensi, dampak, dan kecenderungan pertumbuhan. Urgensi berkaitan dengan waktu. Dampak menggambarkan efek keseriusan masalah, dan kecenderungan pertumbuhan berkaitan dengan pertimbangan di masa mendatang; Keempat, Mencari penyebab. Sangat sulit untuk mencari solusi jika masalahnya tidak diketahui secara pasti. Mengidentifikasi masalah secara benar akan membantu pembuat keputusan menghindari kesalahan dalam penyelesaian.

Kelima, Pengembangan solusi alternatif. Yakni menyusun beberapa pemecahan yang mungkin, kemudian dipilih pemecahan yang paling baik; Keenam, Evaluasi solusi alternatif. Setelah pimpinan mengembangkan beberapa alternatif, langkah berikutnya adalah mengevaluasi semua alternatif. Dalam setiap pengambilan keputusan, pimpinan mempunyai tujuan memilih alternatif yang memberikan hasil yang paling besar keuntungannya atau hasil yang paling kecil kerugiannya. Pimpinan perlu mempunyai pedoman untuk mengadakan perbandingan. Hasil yang akan diperoleh dari tiap-tiap alternatif harus dibandingkan dengan sasaran yang ditetapkan pada langkah pertama. Namun seringkali pimpinan tidak selalu mengetahui dengan pasti hasil dari alternatif tersebut. Ketidaktahuan ini disebabkan oleh adanya tiga macam kemungkinan yang akan dihadapi oleh para pengambil keputusan, yaitu: Kepastian. Pengambilan keputusan memiliki pengetahuan yang lengkap mengenai kemungkinan hasil dari tiap-tiap alternatif. Risiko. Pengambilan keputusan dapat memperkirakan kemungkinan berhasilnya tiap-tiap alternatif. Ketidakpastian. Pengambil keputuan sama sekai tidak memiliki pengetahuan tentang kemungkinan berhasil atau tidaknya tiap-tiap alternatif.

Ketujuh, Pemilihan solusi.Yakni solusi yang paling mungkin dapat mencapai sasaran yang telah ditetapkan bahwa keputusan bukanlah tujuan akhir, tetapi hanya 
satu cara untuk mencapai tujuan. Dalam langkah ini pimpinan memilih satu solusi yang paling mungkin untuk memecahkan pesoalan; Kedelapan, Implementasi. Pada tahapan ini seorang pengambil keputusan (decision maker) harus melaksanakan solusi yang sudah dipilih secara efektif agar sasaran dapat tercapai; Kesembilan, Tindak lanjut. Pemimpin yang efektif melibatkan pengukuran secara periodik terhadap capaian. Hasil yang telah dicapai dibandingkan dengan hasil yang direncanakan (tujuan yang ditetapkan)

Tahapan dalam pengambilan keputusan menurut Colquitt terdiri dari: (1) mengidentifikasi masalah dengan seksama, memeriksa situasi dan mempertimbangkan semua pihak yang berkepentingan, (2) mengembangkan suatu daftar alternatif lengkap untuk dipertimbangkan sebagai solusi, (3) mengevaluasi semua alternatif secara simultan, (4) menggunakan informasi yang akurat untuk mengevaluasi alternatif, (5) memilih alternatif yang memaksimalkan nilai.

Berdasarkan pemaparan di atas maka dapat disintesiskan bahwa pengambilan keputusan adalah proses memilih aksi tertentu untuk merespon peluang dan masalah yang dihadapi oleh seseorang yang meliputi: mengidentifikasi masalah, mengembangkan alternatif, mengevaluasi alternatif, menggunakan informasi, dan memilih alternatif.

\section{METODE}

Penelitian ini dilaksanakan di Sekolah Dasar Negeri Wilayah Jakarta Timur. Penelitian ini dilaksanakan selama 6 (Enam) bulan yang dimulai bulan Juli 2011 sampai dengan bulan Desember 2011. Metode Penelitian yang digunakan dalam melakukan penelitian ini adalah metode survey dengan pendekatan korelasional. Populasi target (target population) dalam penelitian ini adalah seluruh Kepala Sekolah Dasar Negeri di Provinsi DKI Jakarta. Sedangkan populasi terjangkau (study population) adalah Kepala Sekolah Dasar Negeri di Wilayah Kecamatan Kramat Jati sebanyak 90 kepala sekolah. Dalam penelitian ini sampel ditetapkan sebanyak 75 orang. Data penelitian didapat dengan menggunakan instrument. Teknik analisis data penelitian dilakukan dengan statistik deskriptif, uji statistik sederhana dan korelasi sederhana, uji statistik regresi ganda dan korelasi ganda.

\section{HASIL DAN PEMBAHASAN}

Berdasarkan hasil pengujian hipotesis, ternyata ketiga hipotesis yang diajukan, secara signifikan dapat diterima. Uraian masing-masing penerimaan ke tiga hipotesis yang dimaksud dapat dijelaskan sebagai berikut:

1. Hubungan Komunikasi Dengan Kinerja

Pada pengujian hipotesis pertama dapat disimpulkan bahwa terdapat hubungan positif antara komunikasi dengan kinerja. Hubungan ini ditunjukkan oleh nilai $t_{\text {hitung }}$ sebesar 2,756 yang lebih besar dari $t_{\text {tabel }(\mathrm{a}=0,01)}=2,39$. Adapun pola hubungan antara komunikasi dengan kinerja ditunjukkan oleh persamaan $\hat{Y}=43,55+0,629 X_{1}$. 
yang berarti bahwa setiap kenaikan satu skor komunikasi akan diikuti dengan kenaikan kinerja sebesar 0,629 pada arah yang sama dengan konstanta sebesar 43,55.

Hasil analisis korelasi sederhana antara variabel komunikasi dengan kinerja diperoleh nilai koefisien $r_{\mathrm{y} 1}$ sebesar 0,309. Nilai ini memberi pengertian bahwa hubungan komunikasi dengan kinerja adalah signifikan. Artinya semakin baik komunikasi nya maka semakin baik kinerjanyanya.

Besarnya sumbangan atau kontribusi variabel komunikasi dengan variabel kinerja dapat diketahui dengan mengkuadratkan koesfisien korelasi $\mathrm{r}$ yang disebut dengan koefisien determinasi sebesar $\mathrm{r}^{2}=0,096$ Secara statistik nilai ini memberikan pengertian bahwa variasi yang terjadi pada kinerja yang ditentukan oleh komunikasi hanya 9,6\% selebihnya ditentukan oleh faktor lain dengan pola hubungan signifikansinya ditunjukkan oleh persamaan regresi $\hat{Y}=43,55+0,629 X_{1}$.

Dari pembahasan tentang hasil temuan dalam penelitian hubungan antara komunikasi dengan kinerja. Ditemukan bahwa terdapat hubungan antara komunikasi dengan kinerja, Hal ini sesuai dengan yang disampaikan oleh James L. Gibson et al (2006:94) yang menyatakan bahwa perilaku individu yang diantaranya komunikasi berhubungan dengan kinerja. Kemampuan berbicara dan mendengarkan yang efektif ternyata dapat meningkatkan kinerja seseorang yang dalam hal ini kepala sekolah. Kepala sekolah sebagai pemimpin sekolah tentunya sangat dianjurkan memiliki kemampuan berkomunikasi yang baik. Karena dengan kemampuannya dalam berkomunikasi akan sangat membantu dalam mengelola sumber daya yang ada di sekolah, terutama terkait dengan pengelolaan sumber daya manusia. Dengan kemampuannya dalam pengaturan arus informasi, maka komunikasi dapat diatur sedemikian rupa dengan memperhatikan aspek kualitas dan kuantitasnya. Selain itu empati, dalam proses komunikasi seorang kepala sekolah perlu memiliki sikap empatik sehingga ia dapat menangkap bagaimana pesan dapat diterima dan diartikan dengan tepat. Dengan melakukan komunikasi yang efektif akan meningkatkan kinerja kepala sekolah.

\section{Hubungan Pengambilan Keputusan Dengan Kinerja}

Pada pengujian hipotesis kedua dapat disimpulkan bahwa terdapat hubungan positif antara pengambilan keputusan dengan kinerja. Hubungan ini

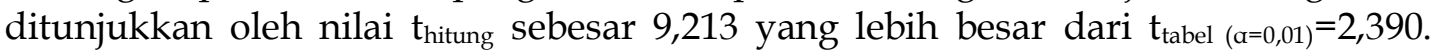
Adapun pola hubungan antara pengambilan keputusan dan kinerja ditunjukkan oleh persamaan $\hat{Y}=43,66+0,712 X_{2}$ yang berarti bahwa setiap kenaikan satu skor pengambilan keputusan akan diikuti dengan kenaikan kinerja sebesar 0,712 pada arah yang sama dengan konstanta sebesar 43,66.

Hasil analisis korelasi sederhana antara variabel pengambilan keputusan dengan Kinerja diperoleh nilai koefisien $r_{\mathrm{y} 2}$ sebesar 0,374. Nilai ini memberi pengertian bahwa hubungan pengambilan keputusan dengan kinerja adalah signifikan. Artinya semakin baik pengambilan keputusannya semakin baik kinerjanya.

Besarnya sumbangan atau kontribusi variabel pengambilan keputusan dengan variabel kinerja dapat diketahui dengan mengkuadratkan koesfisien korelasi $r$ yang disebut dengan koefisien determinasi sebesar $r^{2}=0,140$. Secara statistic nilai ini memberikan pengertian bahwa variasi yang terjadi pada kinerja yang ditentukan 
oleh pengambilan keputusan hanya $14 \%$ selebihnya ditentukan oleh faktor lain dengan pola hubungan signifikansinya ditunjukkan oleh persamaan regresi $\hat{Y}=43,66$ $+0,712 X_{2}$.

Dari pembahasan tentang hasil temuan dalam penelitian hubungan antara pengambilan keputusan dengan kinerja ditemukan bahwa terdapat hubungan yang positif antara pengambilan keputusan dengan kinerja. Hal ini sesuai dengan yang disampaikan oleh Colquitt et al (2009:8) yang menyatakan bahwa dalam suatu organisasi, kinerja merupakan output dalam proses perilaku organisasi yang dipengaruhi oleh mekanisme individu yang salah satunya berupa pengambilan keputusan. Dalam pengambilan keputusan, kepala sekolah perlu memilah aksi tertentu yang dapat dijadikan solusi terbaik dalam penyelesaian masalah sehingga dapat berdampak pada pencapaian tujuan sekolah yang sebelumnya telah ditetapkan.

\section{Hubungan Komunikasi dan Pengambilan Keputusan Dengan Kinerja}

Pada pengujian hipotesis ketiga dapat disimpulkan bahwa terdapat hubungan positif antara komunikasi dan pengambilan keputusan dengan kinerja.

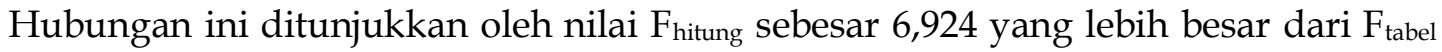
$(\mathrm{a}=0,01)=3,13$. Adapun pola hubungan antara komunikasi dan pengambilan keputusan dengan kinerja ditunjukkan oleh persamaan $\hat{Y}=23,95+0,34 X_{1}+0,56 X_{2}$ yang berarti bahwa setiap kenaikan satu skor komunikasi dan pengambilan keputusan akan diikuti dengan kenaikan kinerja sebesar 0,34 dan 0,56 pada arah yang sama dengan konstanta sebesar 23,95.

Hasil analisis korelasi ganda antara variabel komunikasi dan pengambilan keputusan dengan kinerja diperoleh nilai koefisien $R_{y .12}$ sebesar 0,399. Nilai ini memberi pengertian bahwa hubungan komunikasi dan pengambilan keputusan adalah signifikan. Artinya semakin baik komunikasi dan semakin baik pengambilan keputusannya maka akan semakin baik kinerjanya.

Besarnya sumbangan atau kontribusi variabel komunikasi dan pengambilan keputusan dengan kinerja dapat diketahui dengan mengkuadratkan koesfisien korelasi $\mathrm{r}$ yang disebut dengan koefisien determinasi sebesar $R_{y \cdot 12^{2}}=0,159$. Secara statistik nilai ini memberikan pengertian bahwa variasi yang terjadi pada kinerja yang ditentukan oleh komunikasi dan pengambilan keputusan hanya 15,9\% selebihnya ditentukan oleh faktor lain dengan pola hubungan signifikansinya ditunjukkan oleh persamaan regresi $\hat{Y}=23,95+0,34 X_{1}+0,56 X_{2}$

Dari pembahasan tentang hasil temuan dalam penelitian hubungan antara komunikasi dan pengambilan keputusan dengan kinerja ditemukan bahwa : terdapat hubungan positif antara komunikasi dan pengambilan keputusan dengan kinerja. Hal ini sesuai dengan yang disampaikan oleh Mosley and Megginson (2005:112) yang menyatakan bahwa komunikasi dan pengambilan keputusan secara bersama-sama berhubungan dengan kinerja. Kepala sekolah sebagai pemimpin sekolah sangat dianjurkan memiliki kemampuan berkomunikasi yang baik. Karena dengan kemampuannya dalam berkomunikasi akan sangat membantu dalam mengelola sumber daya yang ada di sekolah, terutama terkait dengan pengelolaan sumber daya manusia. Terkait dengan pengambilan keputusan, agar tidak salah dalam mengambil keputusan, maka kepala sekolah perlu tegas dan bersikap hati-hati dalam memilah mana masukan-masukan yang membangun dan masukan yang melemahkan.

\section{PENUTUP}




\section{Kesimpulan}

Hasil pengujian hipotesis menunjukkan bahwa ketiga hipotesis alternatif $\left(\mathrm{H}_{1}\right)$ yang diajukan dalam penelitian ini diterima, dan menolak hipotesis nol $\left(\mathrm{H}_{0}\right)$. Kesimpulan penelitian dapat dirumuskan sebagai berikut;

1. Terdapat hubungan positif antara komunikasi dengan kinerja. Hal ini memberikan pengertian bahwa keterkaitan antara komunikasi dengan kinerja tergolong positif, artinya semakin baik komunikasi makin baik pula kinerja kepala sekolah. Demikian pula sebaliknya, makin buruk komunikasi makin buruk pula Kinerja Kepala Sekolah Dasar Negeri di Wilayah Kecamatan Kramat Jati.

2. Terdapat hubungan positif antara pengambilan keputusan dengan kinerja. Hal ini memberikan pengertian bahwa keterkaitan antara pengambilan keputusan dengan kinerja tergolong positif, artinya semakin baik pengambilan keputusan makin baik pula kinerja kepala sekolah. Demikian pula sebaliknya, makin buruk pengambilan keputusan makin buruk pula Kinerja Kepala Sekolah Dasar Negeri di Wilayah Kecamatan Kramat Jati.

3. Terdapat hubungan positif antara komunikasi dan pengambilan keputusan secara bersama-sama dengan kinerja. Hal ini memberikan pengertian bahwa keterkaitan antara komunikasi dan pengambilan keputusan dengan kinerja tergolong positif, artinya semakin baik komunikasi dan pengambilan keputusan makin baik pula kinerja kepala sekolah. Demikian pula sebaliknya, makin buruk komunikasi dan pengambilan keputusan makin buruk pula Kinerja Kepala Sekolah Dasar Negeri di Wilayah Kecamatan Kramat Jati.

\section{Implikasi}

Implikasi dari hasil penelitian ini adalah sebagai berikut:

1. Untuk dapat meningkatkan kinerja kepala sekolah diperlukan komunikasi yang efektif. Komunikasi akan berjalan efektif jika kepala sekolah mampu mengatur arus informasi, memiliki empati, mau melakukan tindak lanjut, serta dapat menggunakan bahasa yang dimengerti oleh stakeholders. Dengan komunikasi yang efektif akan berdampak pada peningkatan kinerja kepala sekolah.

2. Untuk dapat meningkatkan kinerja kepala sekolah diperlukan pengambilan keputusan yang tepat dan akurat. Pengambilan keputusan yang tepat dan akurat terwujud jika kepala sekolah mampu melakukan identifikasi masalah, mengembangkan alternatif, mengevaluasi alternatif, menggunakan informasi dan mampu memilih alternatif sebagai dampak pelaksanaan keputusan. Dengan pengambilan keputusan yang tepat akan berdampak pada peningkatan kinerja kepala sekolah

\section{Saran}

Berdasarkan kesimpulan yang telah dikemukakan di atas, maka dapat diajukan beberapa saran dalam memperbaiki komunikasi dan pengambilan keputusan dalam upaya meningkatkan Kinerja Kepala Sekolah Dasar Negeri di Wilayah Kecamatan Kramat Jati. Saran-saran tersebut dapat dikemukakan sebagai berikut:

1. Kepala sekolah diharapkan dapat mengadakan pertemuan rutin bersama stakeholders sekolah sebagai ajang silaturrahim dan menyampaikan informasiinformasi penting. 
2. Dalam mengambil keputusan, kepala sekolah hendaknya mampu mengelola informasi seefektif mungkin yang berguna dalam memilih solusi yang paling tepat diantara beberapa alternatif yang tersedia.

3. Hendaknya kinerja kepala sekolah ditingkatkan secara signifikan dengan cara memenuhi jam mengajarnya sebagai kepala sekolah sebanyak 6 JPL/minggu, aktif dalam forum-forum kepala sekolah, serta memiliki inisiatif yang tinggi untuk memajukan sekolah.

\section{DAFTAR RUJUKAN}

Colquitt, Jason A. Jeffery A. Lepine and Michael J. Wesson, Organizational Behavior. New York : McGraw Hill, 2009.

Dessler, Gary. Human Resource Management, Seventh Edition. New Jersey: Prentice Hall, 1997.

George, Jennifer M. and Gareth R. Jones, Understanding and Managing Organizational Behavior. New Jersey : Pearson Prentice Hall, 2005.

Gibson, James L. et.al., Organizations: Behavior, Structure, Process, Twelfth Edition. New York : McGraw Hill, 2006.

Ivancevich, John M., Robert Konopaske and Michael T. Matteson, Organizational Bahavior and Management, Boston: McGraw-Hill, 2008.

Kreitner, Robert and Angelo Kinicki, Organizational Behavior, Seventh Edition. New York : McGraw Hill, 2007.

McShane, Stephen L and Ann Von Glinow, Organizational Behavior. Fourth Edition. New York: McGraw Hill, 2008.

Mosley, Donald C, Leon C. Megginson, and Paul H.Pietri, Supervisory Management: The Art of Inspiring, Empowering, and Developing People. Ohio : Thomson SouthWestern, 2005.

Nelson, Debra L. and James Campbell Quick, Organizational Behavior, Fifth Edition. USA : Thomson South Western, 2006.

Rivai, Veithzal dan Dato Achmad Fawzi Mohd. Basri, Performance Appraisal. Jakarta : PT. Rajagrafindo Persada, 2005.

Robbins, Stephen P. and Mary Coulter, Management. New Jersey : Pearson Prentice Hall, 2007.

Robbins, Stephen P. and Timothy A. Judge, Organizational Behavior. New Jersey : Pearson Prentice Hall, 2011. 
Slocum and Hellriegel, Principles of Organizational Behavior. New York : South-Western Cengage Learning, 2009.

Vecchio, Robert P., Organizational Behavior, United State: Thomson South-Western, 2006. 